\title{
Review
}

\section{Prognostic biomarkers, pathogenic studies and treatment of Merkel Cell Carcinoma}

\author{
Umair Ali Khan Saddozai ${ }^{1}$, Fengling Wang ${ }^{1}$, Zhang Lu', Longxiang Xie', Zhongyi Yan', \\ Saadullah Khattak ${ }^{1}$, Muhammad Usman Akbar ${ }^{2}$, Muhammad Badar ${ }^{2}$, Wan Zhu ${ }^{3}$, Xinying $\mathrm{Ji}^{1{ }^{1,} \text {, }}$ \\ Xiangqian Guo ${ }^{1, *}$
}

${ }^{1}$ Department of Preventive Medicine, Institute of Biomedical Informatics, Cell Signal Transduction Laboratory, Bioinformatics Center, School of Basic Medical Sciences, Henan University, Kaifeng 475004, China; ${ }^{2}$ Gomal Center of Biochemistry and Biotechnology, Gomal University, Dera Ismail Khan, Pakistan; ${ }^{3}$ Department of Anesthesia, Stanford University, 300 Pasteur Drive, Stanford, CA 94305, USA

*Corresponding author: Xiangqian Guo, E-mail: xqguo@henu.edu.cn; Xinying Ji, E-mail: 10190096@vip.henu. edu.cn

Received May 28, 2019; Accepted August 17, 2019

Merkel cell carcinoma ( $M C C$ ) is a rare type of skin cancer of neuroendocrine origin. MCC found mostly in light-skinned peoples. In the past decades' incidence ratio of MCC have been significantly increased. Numbers of different risk factor has been identified for MCC such as ultraviolet light exposure, advance and immunosuppression. Furthermore newly identified Polyomavirus is also interestingly found in large number of Merkel cell carcinoma patients. This paper will review the MCC evaluation, behavior, tumor size, stages, involvement of virus, treatment, prognostic biomarker and clinical aspects.

Key Words: Merkel cell carcinoma; Skin cancer; Merkel cell polyomavirus; Molecular Aspects

\section{INTRODUCTION}

Merkel cell carcinoma (MCC) was defined for the first time in 1972 by Cyril Toker, ${ }^{1}$ it is reported to be an uncommon neuroendocrine and cutaneous malignancy originating from sweat glands. It is also known as a (neuro) endocrine most cancers of the pores and skin or small-cellular carcinoma of the skin. Merkel cells are thought to arise from the neural crest and are believed to be the number one neural cells discovered as single cells inside the basal layer of the epidermis of the tactile hair disc of Pinkus inside the skin of mammals. Merkel cells are ideal for playing a role as mechanoreceptors and endocrine cells in skin sensory system. ${ }^{1-5}$ Not only being a rare malignancy, but MCC is also an aggressive scientific course. About $66 \%$ of patients have local disease, $27 \%$ have nodal involvement and $7 \%$ have distant metastasis. The immunocompromised, aged people having hematological neoplasms and those who suffered from the cutaneous tumors in the past are at high risk of MCC. There is variation in the incidence ratio of MCC across the different regions of the world.

\section{Epidemiology}

Little is understood concerning the medical specialty of MCC. MCC may be a rare cutaneous tumor. ${ }^{6,7}$ Between 1995 and 2002, 0.13 per 100,000 incidences were reported by the surveillance of Rare Cancer in Europe (RARECARE) database. ${ }^{8,9}$ The incidence rate was recorded as 1.6 per 100,000 individuals per annum in Australian state from $2006-2010^{10}$ and 0.3 per 100,000 individuals in Sweden in $2012 .{ }^{11}$ The median diagnosis age is $75-80$ years. ${ }^{10,11} \mathrm{It}$ is the cancer of neoplasm of elerly people with estimation of 470 new cases within the U.S per year. This incidence figure compares with thirty-one thousand new cases of skin cancer annually. The age-adjusted incidence of MCC in U.S was found to be 0.24 per 100,000 every year. ${ }^{12}$

\section{Clinical issues}

Clinical symptoms of MCC are difficult to detect in the early stages. ${ }^{13,14}$ Clinical presentation of MCC can be variable. Most tumors appear as firm, red to purple, nontender papules or

This is an open access journal, and articles are distributed under the terms of the Creative Commons Attribution-NonCommercial-ShareAlike 4.0 License, which allows others to remix, tweak, and build upon the work non-commercially, as long as appropriate credit is given and the new creations are licensed under the identical terms.

For reprints contact: weda-h@weda-h.org

How to cite this article: Saddozai UAK, Wang FL, Lu Z, Xie LX, Yan ZY, Khattak S, Akbar MU, Badar M, Zhu W, Ji XY, Guo XQ. Prognostic biomarkers, pathogenic studies and treatment of Merkel Cell Carcinoma. J ADV HEALTH 2019; 1(3): 221-226. 
nodules. ${ }^{8}$ Growth is fast and usually dome-shaped. ${ }^{14,15}$ MCC is mostly found on the skin of sun-exposed persons and has been reported on the head, neck, arms, legs, trunk, back, buttock and upper extremities. ${ }^{14-17}$ The head and neck area accounts for $48 \%$ of all MCC cases whereas non-sun-exposed areas are less regularly affected. Mucosal sites for example (larynx, nasal cavity, pharynx, mouth) account for $5 \%$ of primary MCCs. Tumour length may range between 2 to 2 hundred $\mathrm{mm}$. However, it is found most commonly in much less than $20 \mathrm{~mm}$. Merkel cell carcinoma has also been suggested to have an effect on the vulva and penis. ${ }^{8}$ Most affected persons are older than 60 years of age. Five percent of the cases are recognized earlier than the age of fifty. ${ }^{13,14}$ MCC generally observed in the first 3 years following diagnosis. ${ }^{16,18,19}$ Metastasis usually takes place in draining lymph node basin and subsequently expands to other parts of the body. ${ }^{13,16,20}$ A study conducted in 2011 suggested that good enough surgical elimination and selected adjuvant radiotherapy (RT) may reduce the neighborhood recurrence chances. However, sufferers with clinically high-quality lymph nodes have an excessive rate of recurrence in the shape of remote disorder. ${ }^{21}$

\section{Merkel cell polyomavirus}

MCPyV belongs to the family of Polyomaviridae36. Dr Chang and team in their recent studies recognized a unique polyomavirus and introduced it into the order of MCC's genome. Out of ten samples, eight were found to be positive (infected with virus) and further studies confirmed the results. The detection frequency of Merkel cell polyomavirus through polymerase chain reaction was as little as $24 \%$ found in Australian patients and up to $85 \%$ in European and North American patients. ${ }^{22-25}$ Different research strategies are under process to define the virus's role in tumour. There is the latest observation that MCV-positive tumor cells undergo choice for mutations truncating the product of the large $\mathrm{T}$ antigen, thereby stopping virus replication. This proposes that MCV is not a "passenger virus".

\section{Immune Response}

The immune response is a process in tumor progression and is usually centered on the concept of persistent antigen expression as a means of immune down-regulation. Dunn et al. ${ }^{27}$ suggested that cancer cells must interact through three consecutive phases with the host immune system (immune-editing hypothesis). In the elimination phase, the host immune system is able to recognize and destroy newly transformed cells through both the innate and adaptive immune systems. The second equilibrium phase allows the tumor to remain dormant and growth remains stagnant. Lastly, in escape phase, the tumor is able to escape host immune response. Host immune responses are an important part of MCC's progression and prognosis. Some patients with anti-MCPyV antibodies at higher concentrations $(>10,000)$ are found to be more resistant towards progression of MCC and have good survival rate than the patients with low antibody concentrations $(<10,000)$. Antibody concentration against the LT antigen may become potential MCC biomarkers in the future. Rising LT antigen titers have shown to correlate with disease progression and falling titers correlate with successful treatment. ${ }^{28}$ Sihto et al. (2012) suggested the better prognosis from high intratumoral infiltration is not specific to MCPyV-positive MCC; however, it does highlight an important aspect of tumor evasion taking place in the process by which cell surface antigens are known as Major Histocompatibility Complex (MHC) class I antigens are suppressed, allowing presentation of tumor intracellular peptides to CD8+ T lymphocytes. ${ }^{28,29}$ The upregulation of this specific immune response can become major pathway of future MCC treatments.

\section{Molecular Aspects}

Chromosomal abnormalities have been clearly defined in MCC. The most important of which is the loss on the short arm of chromosome $1(1 \mathrm{p} 36)^{30-33}$ that is also found in neuroblastoma pathogenesis $^{34}$ and melanoma, ${ }^{35}$ suggesting that gene of tumor suppressor may be confined here. The $p 73$ has been found to localize $1 \mathrm{p} 36^{36,37}$ but the latest study found mutations of the $p 73$ gene in one out of 10 sufferers with MCC, ${ }^{38}$ which were much like the infrequent mutations of $p 73$ in cancer. ${ }^{39}$ The tumor-suppressing gene ( $p 53)$ is thought to express temporarily in MCC. Whereas mutant $p 53$ protein was found in 6 out of 9 patients with poor clinical outcomes as compared to 0 out of 10 patients with more favorable outcomes. ${ }^{40}$ Every other critical abnormality may be reported as a lack of heterozygosity in chromosome $3 \mathrm{p} 21^{41,42}$ but the same region is also affected in more than $90 \%$ of patients suffering from small-cell lung cancers. Newly postulated tumor suppressors gene (Ras association domain family 1 RASSF1A) belongs to the origin of neuroendocrine cells, ${ }^{43,44}$ which also indicates histological parts of small blue cells and early metastasize tendency. Lots of other different chromosomal abnormalities are also defined in MCC including trisomy 1 , trisomy 6 , trisomy 11 , trisomy $18^{45-49}$ and deletion of chromosome $7 .{ }^{46}$ The loss of heterozygosity is also found in chromosome 10q (50) and chromosome 13. According to reports, a common deletion of the retinoblastoma gene RB1 was found in one study. ${ }^{48,51,52}$ Moreover, various studies demonstrated the involvement of oncogenes or tumor suppressing genes in MCC pathogenesis. However, too little is known related to the prognostic value of reported abnormalities and no significant applicants have been found so far.

\section{Prognosis and staging}

Due to the aggressive nature of MCC, MCC patients have dismal outcomes based on historical data in small case series. ${ }^{13}$ However, MCC is not uniformly lethal. ${ }^{18}$ Most patients with MCC (70\% to $80 \%$ ) present localized disease, $10 \%$ to $30 \%$ have regional lymph node involvement, whereas $1 \%$ to $7 \%$ have distant metastases at the time of initial presentation. ${ }^{53-56}$ It is found that five-year survival rate for patients treated with local metastasis to regional lymph node ranges from $26 \%$ to $40 \%$. But the 5 year survival rate of the patient with distant metastasis is $18 \%{ }^{8,12}$ However, overall survival rate of MCC patients ranges from $30 \%$ to $75 \%{ }^{13}$ Therefore Consensus staging system with four main stages of the cancer was introduced in 2010 by the American Joint Committee on Cancer (AJCC). Which based on tumor size, nodal involvement and the presence of distant metastasis ${ }^{57,58}$ SLNB (sentinel lymph node biopsy) is recommended for accurate staging. Similarly in 2016 a new advanced staging system was developed which separates groups of clinical and pathological stages. This reflects more precisely the difference in patient outcomes observed for these two methods of staging. ${ }^{59}$ 


\section{Biomarkers}

Platelet-derived growth factor (PDGF) receptor, c-kit (CD117) and phosphoinositide 3-kinase (PI3K) are often overexpressed in MCC tumors, which may be linked to a worse prognosis for patients with MCC. ${ }^{60-62}$ Although the analysis of tumor specimens with PI3K mutations suggests a more aggressive tumor pathology, an association between PI3K mutation status and patient survival has not yet been established. ${ }^{61}$ Several other biomarkers including PD-L1, p63, vascular endothelial growth factor receptor (VEGFR), Ki-67, CD34, Ep-CAM, nuclear factor kappa B, sonic hedgehog pathway proteins and matrix metalloproteinase have been suggested to predict disease outcomes in patients with MCC. ${ }^{63-70}$ However, comprehensive data to assign any specific biomarker to prognostic associations is still unavailable.

\section{Quality of life}

Almost all patients diagnosed with MCC have a similar quality of life. Generally, the patients are elder and suffer from other medical comorbidities. Patients above 75 years of age lack potential to tolerate multi-model treatment. ${ }^{71}$ Such multi-model treatments include variety of therapeutic strategies such as radiotherapy, locoregional surgery, systemic cytotoxic and focused or immune remedy. Therefore, an onco-geriatric assessment is required in selected patients before determining a control path. It has become very important to minimize the adverse effects associated with therapies. Acute toxicity arising from side effects can be fatal and have long term repercussions and patients' health. As MCC is a rare carcinoma, there are no valid MCC-particular quality-of-life measurement instruments and dermatology-specific instruments have not been validated for patients with MCC.

Further to the impact of receiving a prognosis of this aggressive cutaneous malignancy, treatment-associated toxicity could have a prime impact on patient's lifestyles. Thus, with old age patients having couple of comorbidities, various rapid-appearing and easy-to-use interventions (frequently radiotherapy alone) might be taken into consideration. The usage of systemic cytotoxic treatments in MCC management remains controversial with likely concerns in elderly sufferers. Inside the palliative placing, responses are frequently short-lived, and patient's quality of existence is more affected by treatment than by means of the disease. Application of chemotherapy in old age patients having superior-level MCC becomes difficult to complete the planned chemotherapy direction. ${ }^{72}$ However, improved efficacy and less toxicity of inhibitors make them a better option to use on this population. ${ }^{73}$ The adverse effects of treatment on the lifestyles of patients cannot be underestimated as treatment-related toxicity is the priority of any management course and the goal of future research.

\section{Treatment of MCC}

Surgical excision is the strength of treatment for MCC patients. ${ }^{18,74,75}$ For the treatment with Mohs micrographic surgery or local excision the Current National Comprehensive Cancer Network guidelines recommend a margin of $1-2 \mathrm{~cm}$. Patients undergoing wide local excision also required the compulsory intraoperative sentinel lymph node biopsy. Similarly preoperative sentinel lymph node biopsy is needed for patients undergoing Mohs micrographic surgery because of change in lymphatic drainage which could affect lymphoscintigraphy. ${ }^{8}$ The effect of radiation therapy also plays an important role against MCC due to sensitivity. ${ }^{74,76,77}$ For MCC, patient's radiation may be used as adjuvant or primary therapy, whereas non-surgical candidate uses reserved radiation as primary therapy.

No difference has been found between the outcome of a small group of patients treated with radiation alone and patients who underwent surgery and radiation to the tumor bed. ${ }^{8}$ There is a trendy consensus that radiation treatment is advantageous for recurrent tumors. Chemotherapy is a good option as a pain killer therapy for stage IV cancer patients but only two-third of tumors respond to chemotherapy and the disease often recurs after few months. Current guidelines suggest that a small group of patients may not require adjuvant therapy following adequate resection of some small tumors and that the clinical observation may be appropriate. ${ }^{8,12}$ Chemotherapy may play a palliative role in patients with metastatic MCC. MCC is chemo-sensitive but with a high recurrence rate. ${ }^{8}$ The immune system plays an important role in disease prognosis and having an intact immune system is a plus point in the prevention of disease progression.

\section{Future Treatments of MCC}

Upregulation of immune response and viral etiology of the most tumor would be the focus for the future treatments of MCC, which may help in interfering with viral oncoproteins and in stimulating different immune responses against tumor cells. ${ }^{28}$ Interestingly, in some tumors, MCPyV large $\mathrm{T}$ antigen was found to be overexpressed and may serve as definite target for new therapy. ${ }^{78,79}$

LT antigen encoding key cycle surviving protein may be an exciting marker given its implication in many different cancers. ${ }^{80}$ Other prospective non-viral molecular objectives are antigens containing the oncoprotein H1P1 that interacts with c-KIT. Specific immune-stimulatory cytokines that may be used to upregulate the immune response towards the tumoral cells may include IL-2, IL-12, IL-15, or IL-21. Therapeutic agents may become the main focus of study in the future to set a target immune exhaustion phenomenon related to tumorigenesis containing ipilimumab (cytotoxic $\mathrm{T}$ lymphocyte antigen 4 receptor-blocking agent). It also needs a focus on programmed cell death 1 ligand 1 and programmed cell death 1 (PD-1/PD-L1). ${ }^{28}$ Tumour of neuroendocrine containing MCC tends to express vascular and highly vascular endothelial growth factors, and platelet of growth factors, which may become other possible therapeutic targets. According to reports, 95\% patients of MCC are $\mathrm{CD} 56+$, and present clinical trials suggest a promising therapeutic response with anti-CD56 monoclonal antibody. ${ }^{12}$

\section{CONCLUSION}

Great development has been made in our expertise of MCC tumor biology and immunology. The occurrence of MCC is increasing due to the advancing age of the populace, a higher prevalence of negative solar exposure, and an increase in the number of immunecompromised people. Merkel cell polyomavirus keeps importance regarding the etiology of MCC. However, the local or regional treatments have their value and they remain standard of care. Adjuvant radiotherapy or radiotherapy on its own has been found to be affordable therapeutic options. Such progressed understanding is gradually and effectively translated into the medical situation. For this reason, the mortality charge and diagnosis of patients 
imparting with advanced ailment have remained exceedingly unchanged. The latest advances within the development of properly tolerated immunotherapy sellers will have the capacity to offer effective remedy alternatives for sufferers with advanced or recurrent MCC in near future.

\section{Conflict of interest}

We all authors declare that we have no conflicts of interest for this article.

\section{Funding}

This work was supported by the National Natural Science Foundation of China (No. 81602362 to XG), the program for Science and Technology Development in Henan Province (No.162102310391 to XG), the program for Young Key Teacher of Henan Province (No.2016GGJS-214 to XG), the supporting grants of Henan University (No.2015YBZR048 to XG; No.B2015151 to $\mathrm{XG})$, the program for Innovative Talents of Science and Technology in Henan Province (No. 18HASTIT048 to XG), and Yellow River Scholar Program (No.H2016012 to XG). The funding bodies were not involved in the study design, data collection, analysis and interpretation of data, or in writing of this manuscript.

\section{REFERENCES}

1. Toker C. Trabecular carcinoma of the skin. A question of title. Am J Dermatopathol 1982; 4(5): 497-500.

2. Winkelmann RK, Breathnach AS. The Merkel cell. J Invest Dermatol 1973; 60(1): 2-15.

3. Haag ML, Glass LF, Fenske NA. Merkel cell carcinoma. Diagnosis and treatment. Dermatol Surg 1995; 21(8): 669-83.

4. Halata Z, Grim M, Bauman KI. Friedrich Sigmund Merkel and his "Merkel cell", morphology, development, and physiology: review and new results. Anat Rec A Discov Mol Cell Evol Biol 2003; 271(1): 225-39.

5. Lucarz A, Brand G. Current considerations about Merkel cells. Eur J Cell Biol 2007; 86(5): 243-251.

6. Agelli M, Clegg LX. Epidemiology of primary Merkel cell carcinoma in the United States. J Am Acad Dermatol 2003; 49(5): 832-41.

7. Hodgson NC. Merkel cell carcinoma: changing incidence trends. $J$ Surg Oncol 2005; 89(1): 1-4.

8. Han SY, North JP, Canavan T, Kim N, Yu SS. Merkel cell carcinoma. Hematol Oncol Clin N Am 2012; 26(6): 1351-74.

9. van der Zwan JM, Trama A, Otter R, Larrañaga N, Tavilla A, MarcosGragera R, Dei Tos AP, Baudin E, Poston G, Links T; RARECARE WG. Rare neuroendocrine tumours: results of the surveillance of rare cancers in Europe project. Eur J Cancer 2013; 49(11):2565-78.

10. Youlden DR, Soyer HP, Youl PH, Fritschi L, Baade PD. Incidence and survival for Merkel cell carcinoma in Queensland, Australia, 1993-2010. JAMA Dermatol 2014; 150(8): 864-72.

11. Zaar O, Gillstedt M, Lindelöf B, Wennberg-Larkö AM, Paoli J. Merkel cell carcinoma incidence is increasing in Sweden. J Eur Acad Dermatol Venereol 2016; 30(10): 1708-1713.

12. Donepudi S, DeConti RC, Samlowski WE. Recent advances in the understanding of the genetics, etiology, and treatment of merkel cell carcinoma. Semin Oncol 2012; 39(2): 163-72.

13. Bichakjian CK, Lowe L, Lao CD, Sandler HM, Bradford CR, Johnson TM, Wong SL. Merkel cell carcinoma: critical review with guidelines for multidisciplinary management. Cancer 2007; 110(1):1-12.
14. Heath M, Jaimes N, Lemos B, Mostaghimi A, Wang LC, Peñas PF, Nghiem P. Clinical characteristics of Merkel cell carcinoma at diagnosis in 195 patients: the AEIOU features. J Am Acad Dermatol 2008; 58(3): 375-81.

15. Smith VA, Camp ER, Lentsch EJ. Merkel cell carcinoma: identification of prognostic factors unique to tumors located in the head and neck based on analysis of SEER data. Laryngoscope 2012; 122(6):1283-90.

16. Medina-Franco H, Urist MM, Fiveash J, Heslin MJ, Bland KI, Beenken SW. Multimodality treatment of Merkel cell carcinoma: case series and literature review of 1024 cases. Ann Surg Oncol 2001; 8(3): 204-8.

17. Hussain SK, Sundquist J, Hemminki K. Incidence trends of squamous cell and rare skin cancers in the Swedish national cancer registry point to calendar year and age-dependent increases. J Invest Dermatol 2010; 130(5): 1323-8.

18. Allen PJ, Bowne WB, Jaques DP, Brennan MF, Busam K, Coit DG. Merkel cell carcinoma: prognosis and treatment of patients from a single institution. J Clin Oncol 2005; 23(10): 2300-9.

19. Jabbour J, Cumming R, Scolyer RA, Hruby G, Thompson JF, Lee S. Merkel cell carcinoma: assessing the effect of wide local excision, lymph node dissection, and radiotherapy on recurrence and survival in early stage diseaseeresults from a review of 82 consecutive cases diagnosed between 1992 and 2004. Ann Surg Oncol 2007; 14(6): 1943-52.

20. Voog E, Blay JY. Merkel cell carcinoma: diagnostic and treatment. Bull Cancer 1999; 86(7-8): 625-30.

21. Fields RC, Busam KJ, Chou JF, Panageas KS, Pulitzer MP, Allen PJ, et al. Recurrence after complete resection and selective use of adjuvant therapy for stage I through III Merkel cell carcinoma. Cancer 2012; 118(13): 3311-20.

22. Feng $\mathrm{H}$, Shuda $\mathrm{M}$, Chang $\mathrm{Y}$, Moore PS. Clonal Integration of a polyomavirus in human Merkel cell carcinoma. Science 2008; 319(5866): 1096-100.

23. Kassem A, Schoepflin A, Diaz C, et al. Frequent detection of Merkel cell polyomavirus in human Merkel cell carcinomas and identification of a unique deletion in the VP1 gene. Cancer Res 2008; 68: 5009-5013.

24. Garneski KM, Warcola AH, Feng Q, Kiviat NB, Leonard JH, Nghiem P. Merkel cell polyomavirus is more frequently present in North American than Australian Merkel cell carcinoma tumors. J Invest Dermatol 2009; 129(1): 246-8.

25. Becker JC, Houben R, Ugurel S, Trefzer U, Pföhler C, Schrama D. MC polyoma virus is frequently present in Merkel cell carcinoma of European patients. J Invest Dermatol 2009; 129(1): 248-50.

26. Shuda M, Feng H, Kwun HJ, Rosen ST, Gjoerup O, Moore PS, Chang Y. T antigen mutations are a human tumor-specific signature for Merkel cell polyomavirus. Proc Natl Acad Sci U S A 2008; 105(42): 16272-7.

27. Dunn GP, Bruce AT, Ikeda H, Old LJ, Schreiber RD. Cancer immunoediting: from immunosurveillance to tumor escape. Nat Immunol 2002; 3(11): 991-998.

28. Bhatia S, Afanasiev O, Nghiem P. Immunobiology of Merkel cell carcinoma: implications for immunotherapy of a polyomavirusassociated cancer. Curr Oncol Rep 2011; 13: 488-497.

29. Sihto H, Böhling T, Kavola H, Koljonen V, Salmi M, Jalkanen S, Joensuu H. Tumor infiltrating immune cells and outcome of Merkel cell carcinoma: a population-based study. Clin Cancer Res 2012; 18(10): 2872-81.

30. Harnett PR, Kearsley JH, Hayward NK, Dracopoli NC, Kefford RF. Loss of allelic heterozygosity on distal chromosome $1 \mathrm{p}$ in Merkel cell carcinoma: A marker of neural crest origins? Cancer Genet Cytogenet 
1991; 54(1): 109-13.

31. Van Gele M, Van Roy N, Ronan SG, Messiaen L, Vandesompele J, Geerts ML, Naeyaert JM, Blennow E, Bar-Am I, Das Gupta TK, van der Drift P, Versteeg R, Leonard JH, Speleman F. Molecular analysis of p36 breakpoints in two Merkel cell carcinomas. Genes Chromosomes Cancer 1998(1); 23:67-71.

32. Judson H, van Roy N, Strain L, Vandesompele J, Van Gele M, Speleman F, Bonthron DT. Structure and mutation analysis of the gene encoding DNA fragmentation factor 40 (caspaseactivated nuclease), a candidate neuroblastoma tumour suppressor gene. Hum Genet 2000; 106(4): 406-13.

33. Leonard JH, Cook AL, Nancarrow D, Hayward N, Van Gele M, Van Roy N, Speleman F. Deletion mapping on the short arm of chromosome 1 in Merkel cell carcinoma. Cancer Detect Prev 2000; 24(6): 620-7.

34. Maris JM, Matthay KK. Molecular biology of neuroblastoma. J Clin Oncol 1999; 17(7): 2264-79.

35. Smedley D, Sidhar S, Birdsall S, Bennett D, Herlyn M, Cooper C, Shipley J. Characterization of chromosome 1 abnormalities in malignant melanomas. Genes Chromosomes Cancer 2000; 28(1): 121-125.

36. Kaghad M, Bonnet H, Yang A, Creancier L, Biscan JC, Valent A, Minty A, Chalon P, Lelias JM, Dumont X, Ferrara P, McKeon F, Caput D. Monoallelically expressed gene related to p53 at $1 \mathrm{p} 36$, a region frequently deleted in neuroblastoma and other human cancers. Cell 1997; 90(4): 809-819.

37. Soltau JB, Smith ME, Custer PL. Merkel cell carcinoma of the eyelid. Am J Ophthalmol 1996; 121(3): 331-332.

38. Van Gele M, Kaghad M, Leonard JH, Van Roy N, Naeyaert JM, Geerts ML, Van Belle S, Cocquyt V, Bridge J, Sciot R, De Wolf-Peeters C, De Paepe A, Caput D, Speleman F. Mutation analysis of P73 and TP53 in Merkel cell carcinoma. Br J Cancer 2000; 82(4): 823-826.

39. Tsao H, Zhang X, Majewski P, Haluska FG. Mutational and expression analysis of the p73 gene in melanoma cell lines. Cancer Res 1999; 59(1): 172-174.

40. Carson HJ, Lueck NE, Horten BC. Comparison of mutant and wild-type p53 proteins in Merkel cell carcinoma. Clin Diagn Lab Immunol 2000; 7(2): 326.

41. Leonard JH, Williams G, Walters MK, et al. Deletion mapping of the short arm of chromosome 3 in Merkel cell carcinoma. Genes Chromosomes Cancer 1996; 15: 102-107.

42. Sonak RA, Trede K, Gerharz CD. Merkel cell tumor of the hand in a 104-year-old patient: Case report with review of the literature. Handchir Mikrochir Plast Chir 1996; 28: 43-45.

43. Dammann R, Li C, Yoon JH, et al. Epigenetic inactivation of a RAS association domain family protein from the lung tumour suppressor locus 3p21.3. Nat Genet 2000; 25: 315-319.

44. Burbee DG, Forgacs E, Zochbauer-Muller S, et al. Epigenetic inactivation of RASSF1A in lung and breast cancers and malignant phenotype suppression. J Natl Cancer Inst 2001; 93: 691-699.

45. Harle M, Arens N, Moll I, et al. Comparative genomic hybridization (CGH) discloses chromosomal and subchromosomal copy number changes in Merkel cell carcinomas. J Cutan Pathol 1996; 23: 391-397.

46. Sandbrink F, Muller L, Fiebig HH, et al. Short communication: Deletion 7q, trisomy 6 and 11 in a case of Merkel-cell carcinoma. Cancer Genet Cytogenet 1988; 33: 305-309.

47. Larsimont D, Verhest A. Chromosome 6 trisomy as sole anomaly in a primary Merkel cell carcinoma. Virchows Arch 1996; 428: 305- 309.

48. Leonard JH, Leonard P, Kearsley JH. Chromosomes 1, 11, and 13 are frequently involved in karyotypic abnormalities in metastatic Merkel cell carcinoma. Cancer Genet Cytogenet 1993 67: 65-70.
49. Amo-Takyi BK, Tietze L, Tory K, et al. Diagnostic relevance of chromosomal in-situ hybridization in Merkel cell carcinoma: Targeted interphase cytogenetic tumour analyses. Histopathology 1993; 34: 163-169.

50. Van Gele M, Leonard JH, van Roy N, et al. Frequent allelic loss at 10q23 but low incidence of PTEN mutations in Merkel cellcarcinoma. Int J Cancer 2001; 92: 409-413.

51. Leonard JH, Hayard N. Loss of heterozygosity of chromosome 13 in Merkel cell carcinoma. Genes Chromosomes Cancer 1997; 20: 93-97.

52. Van Gele M, Speleman F, Vandesompele J, et al. Characteristic pattern of chromosomal gains and losses in Merkel cell carcinoma detected by comparative genomic hybridization. Cancer Res 1998; 58: 1503-1508.

53. Hitchcock CL, Bland KI, Laney RG III, et al. Neuroendocrine (Merkel cell) carcinoma of the skin: Its natural history, diagnosis, and treatment. Ann Surg 1988; 207: 201-207.

54. Yiengpruksawan A, Coit DG, Thaler HT, Urmacher C, Knapper WK. Merkel cell carcinoma. Prognosis and management. Arch Surg 1991; 126: 1514-9.

55. Shaw JH, Rumball E. Merkel cell tumour: Clinical behaviour and treatment. Br J Surg 1991; 78: 138-142.

56. Meyer-Pannwitt U, Kummerfeldt K, Boubaris P, et al. Merkel cell tumor or neuroendocrine skin carcinoma. Langenbecks Arch Chir 1997; 382: 349-358.

57. Lemos BD, Storer BE, Iyer JG., Phillips JL, Bichakjian CK, Fang LC, et al. Pathologic nodal evaluation improves prognostic accuracy in Merkel cell carcinoma: analysis of 5823 cases as the basis of the first consensus staging system. J Am Acad Dermatol 2010; 63(5): 751-61.

58. Edge SB, Compton CC. The American Joint Committee on Cancer: the 7th edition of the AJCC cancer staging manual and the future of TNM. Ann Surg Oncol 2010; 17(6): 1471-4.

59. Harms KL, Healy MA, Nghiem P, Sober AJ, Johnson TM, Bichakjian CK, Wong SL. Analysis of prognostic factors from 9387 Merkel cell carcinoma cases forms the basis for the new 8th edition AJCC staging system. Ann Surg Oncol 2016; 23(11): 3564-71.

60. Andea AA, Patel R, Ponnazhagan S, Kumar S, DeVilliers P, Jhala D, et al. Merkel cell carcinoma: correlation of KIT expression with survival and evaluation of KIT gene mutational status. Hum Pathol 2010; 41(10): 1405-12.

61. Nardi V, Song Y, Santamaria-Barria JA, Cosper AK, Lam Q, Faber AC, et al. Activation of PI3K signaling in Merkel cell carcinoma. Clin Cancer Res 2012; 18(5): 1227-36.

62. Swick BL, Srikantha R, Messingham KN. Specific analysis of KIT and PDGFR-alpha expression and mutational status in Merkel cell carcinoma. J Cutan Pathol 2013; 40(7): 623-30.

63. Kurzen H, Kaul S, Egner U, Deichmann M, Hartschuh W. Expression of MUC 1 and ep-CAM in Merkel cell carcinomas: implications for immunotherapy. Arch Dermatol Res 2003 ; 295(4): 146-54.

64. Fernandez-Figueras MT, Puig L, Musulen E, Gilaberte M, Ferrandiz C, Lerma E, et al. Prognostic significance of p27Kip1, p45Skp2 and Ki67 expression profiles in Merkel cell carcinoma, extracutaneous small cell carcinoma, and cutaneous squamous cell carcinoma. Histopathology 2005; 46(6): 614-21.

65. Fernandez-Figueras MT, Puig L, Musulen E, Gilaberte M, Lerma E, Serrano S, et al. Expression profiles associated with aggressive behavior in Merkel cell carcinoma. Mod Pathol 2007; 20(1): 90-101.

66. Ng L, Beer TW, Murray K. Vascular density has prognostic value in Merkel cell carcinoma. Am J Dermatopathol 2008; 30(5): 442-5.

67. Brunner M, Thurnher D, Pammer J, Heiduschka G, Petzelbauer P, Schmid C, et al. Expression of hedgehog signalling molecules in Merkel cell carcinoma. Head Neck 2010; 32(3) 333-40.

68. Asioli S, Righi A, de Biase D, Morandi L, Caliendo V, Picciotto F, et 
al. Expression of p63 is the sole independent marker of aggressiveness in localised (stage IeII) Merkel cell carcinomas. Mod Pathol 2011; 24(11).

69. Stetsenko GY, Malekirad J, Paulson KG, Iyer JG, Thibodeau RM, Nagase K, et al. p63 expression in Merkel cell carcinoma predicts poorer survival yet may have limited clinical utility. Am J Clin Pathol 2013; 140(6): 838-44.

70. Lipson EJ, Vincent JG, Loyo M, Kagohara LT, Luber BS, Wang H, et al. PD-L1 expression in the Merkel cell carcinoma microenvironment: association with inflammation, Merkel cell polyomavirus and overall survival. Cancer Immunol Res 2013; 1(1): 54-63.

71. Ferrat E, Paillaud E, Caillet P, Laurent M, Tournigand C, Lagrange JL, Droz JP, Balducci L, Audureau E, Canouï-Poitrine F, Bastuji-Garin S. Performance of four frailty classifications in older patients with cancer: prospective elderly cancer patients cohort study. J Clin Oncol 2017; 35(7): 766-777.

72. Gorayski P, Tripcony L, Poulsen M. Chemotherapy compliance in high-risk Merkel cell carcinoma treated with chemoradiotherapy. Australas J Dermatol 2017; 58(1): 35-41.

73. Kanz BA, et al. Safety and efficacy of anti-PD-1 in patients with baseline cardiac, renal, or hepatic dysfunction. J Immunother Cancer
2016; 4: 60 .

74. Miller SJ, Alam M, Andersen J, et al. National Comprehensive Cancer Network. Merkel cell carcinoma. J Natl Compr Canc Netw 2006; 4: 704-712.

75. Vazmitel M, Michal M, Kempf W, et al. Merkel cell carcinoma with a follicular lymphocytic infiltrate: report of 2 cases. Am J Dermatopathol 2008; 30: 389-391.

76. Eng TY, Boersma MG, Fuller CD, et al. A comprehensive review of the treatment of Merkel cell carcinoma. Am J Clin Oncol 2007; 30: 624-636.

77. Garnski KM, Warcola AH, Feng Q, et al. Merkel cell polyomavirus is more frequently present in North American than Australian Merkel cell carcinoma tumors. J Invest Dermatol 2009; 129: 246-248.

78. Erovic B, Al Habeeb A, Harris L, et al. Significant overexpression of the Merkel cell polyomavirus (MCPyV) large T antigen in Merkel cell carcinoma. Head Neck 2013; 35: 184-189.

79. Angermeyer S, Hesbacher S, Becker J, et al. Merkel cell polyomaviruspositive Merkel cell carcinoma cells do not require expression of the viral small T antigen. J Invest Dermatol 2013; 133: 1-6.

80. Arora R, Shuda M, Guastafierro A, et al. Survivin is a therapeutic target in Merkel cell carcinoma. Sci Transl Med 2012; 4: 1-11. 